\title{
A Fresh Start for Screening under the Habitats Regulations: Case C-323/17 People Over Wind, Peter Sweetman v Coillte Teoranta [2018] ECR I-244
}

\author{
Richard Broadbent \\ Head of Legal Services, Natural England, Exeter, UK \\ Catherine Ann Caine \\ Lecturer in Environmental and Planning Law, University of Exeter, UK
}

Key words

Habitats Directive, appropriate assessment, screening, mitigation

\section{Introduction}

For over twenty-five years, the Habitats Directive has faced significant scrutiny from commentators, practitioners and developers alike. Every element of the Directive's requirements has been interpreted and assessed by Member States, and many cases have come before the Court of Justice of the European Union (CJEU), resulting in further definition and refinement of the Directive's requirements. One such judgment that can be added to this long list of authority is People Over Wind and Peter Sweetman v Coillte Teorant (People Over Wind). ${ }^{1}$

The judgment focuses solely on the screening process for appropriate assessment, specifically the extent to which potential mitigation can be considered at this stage. This judgment not only represents another page in the book of refining the requirements of the Habitats Directive, but also has significant repercussions in terms of its application in England. This is because it directly contradicts a series of judgments that have been delivered in English courts. Given the binding nature of CJEU judgments, People Over Wind will result in a shift in judicial response to the next decision to reach the English courts. Significantly it will have a knock-on impact now on developers, competent authorities, and decision-makers because what was hitherto accepted as capable of being screened out of a Habitats Regulations Assessment must now be subject to an appropriate assessment. This will increase the resources required to process a greater number of appropriate assessments as a result of this ruling.

Facts

The proceedings were brought by the environmental NGO, People Over Wind, and Peter Sweetman against the proposal made by Coillte Teoranta (Coillte) to lay cable to connect a consented wind farm to the electricity grid. The area of proposed cable laying activities intersects the River Barrow and the River Nore in Ireland, both of which are designated as Special Areas of Conservation (SACs) under the Habitats Directive in order to protect the Nore pearl mussel. ${ }^{2}$ It was noted in the judgment that the species has not reproduced since 1970, and

\footnotetext{
${ }^{1}$ Case C-323/17 People Over Wind, Peter Sweetman v Coillte Teoranta [2018] ECR I-244.

${ }^{2}$ Margaritifera durrovensi as designated under annex 2 of Council Directive 92/43/EEC (OJ L206/7

22.7.93) on the conservation of natural habitats and of wild fauna and flora ('the Habitats Directive').
} 
forecasts suggest that it is threatened with extinction as it is particularly sensitive to river siltation. ${ }^{3}$

In 2013, consent for the wind farm was granted subject to conditions. Under condition 17 a Construction Management Plan was required with a specific requirement under 17(k) to ensure that 'water run-off is controlled such that no silt or other pollutants enter watercourses' ${ }^{4}$ The applicants in this case contend that the proposed action of cable laying, as outlined by Coillte, would result in siltation of the river and would therefore have a harmful effect on the Nore pearl mussel.

The judgment records that there was a dispute as to whether the laying of the cable is 'exempted development' not requiring consent. However, whilst the developer claimed that the cable laying activities were exempted development, they accepted that if an appropriate assessment was required then planning permission would have to be obtained. In order to determine whether an appropriate assessment was required, Coillte's consultants created a screening report. Within this report, it was concluded that in the absence of protective measures, there was potential for sediment release and siltation, and that if such release were to enter into the pearl mussel population area of the river, 'there would be a negative impact on the pearl mussel population' ${ }^{5}$ Various protective measures were analysed, with the report ultimately arriving at the conclusion that 'the grid connection works will not have a significant effect on the relevant European sites... and an appropriate assessment is not required'. ${ }^{6}$ This conclusion was clearly reliant on the fact that mitigation measures had been factored into the screening report. It was noted in the judgment that the 'protective measures proposed and taken into account by the authors of that [screening report] are not as stringent as those required in condition $17(\mathrm{k})$ of the planning permission for the wind farm concerned'. ${ }^{7}$

It was concern over this that prompted the High Court in Ireland, to refer the following question to the Court of Justice for a preliminary ruling:

Whether, or in what circumstances, mitigation measures can be considered when carrying out screening for appropriate assessment under Article 6(3) of the Habitats Directive ${ }^{8}$

The fact that more stringent planning conditions could have been imposed had an appropriate assessment been required appears important to the way in which the CJEU approached the case as it may have given the impression that the approach was a circumvention of the strict protections under the Article 6(3).

\section{The judgment}

The judgment is short in length and confident in its assertions. Indeed, the CJEU were so confident that after hearing the Advocate General they decided to proceed to judgment without an opinion. Consideration of the question begins with the reassertion that Article 6 of the Habitats Directive 'must be construed as a coherent whole in the light of the conservation

\footnotetext{
${ }^{3}$ See People Over Wind, above n. 1 at para. 11.

${ }^{4}$ Ibid. at para. 12.

${ }^{5}$ Ibid. at para. 17.

${ }^{6}$ Ibid. at para. 19.

${ }^{7}$ Ibid. at para. 21.

${ }^{8}$ Ibid. at para. 22.
} 
objectives pursued by the directive'. ${ }^{9}$ The requirements of Articles 6(2), 6(3) and 6(4) are subsequently analysed, with the overall purpose of Article 6 being described as divided into three categories: conservation measures, preventive measures and compensatory measures. ${ }^{10}$ What is very clearly noted in the judgment, is that the wording of Article 6 contains 'no reference to any concept of "mitigating measure". .11 Furthermore, both the terms "mitigating measures' and 'protective measures' had been used by the parties and the Court sought to clarify these terms by interpreting them as 'denoting measures that are intended to avoid or reduce the harmful effects of the envisaged project on the site concerned. ${ }^{\prime 2}$

In analysing the requirements of the Habitats Directive, reference was made to previous conclusions drawn from CJEU case law - namely that Article 6(3) of the Directive ${ }^{13}$ can be divided into two stages:

1. The requirement upon Member States to conduct an appropriate assessment for a plan or project not connected with or necessary to the management of the site where there is a likelihood of significant effect on a designated site

2. The requirement after such an appropriate assessment has been carried out not to permit a plan or project if it will adversely affect the integrity of the site concerned. Stage two is subject to the provisions under Article 6(4) whereby notwithstanding a finding of adverse effect on integrity, a plan or project can be permitted if there are no alternatives and there are imperative reasons of overriding public interest. ${ }^{14}$

With regards the first stage, the cable laying activities clearly do not fall within the remit of management of the site. With regards to the second stage, which falls at the crux of the judgment, the Court concluded that:

The fact that... measures intended to avoid or reduce the harmful effects of a plan or project on the site concerned are taken into consideration when determining whether it is necessary to carry out an appropriate assessment presupposes that it is likely that the site is affected significantly and that, consequently, such an assessment should be carried out. ${ }^{15}$

In other words, the CJEU said that the very fact that mitigation measures were proposed at the screening stage by the developer confirms that the proposed project would have a significant effect. Building on this assertion, the Court said that:

Taking account of such measures at the screening stage would be liable to compromise the practical effect of the Habitats Directive in general, and the assessment stage in particular, as the latter stage would be deprived of its purpose and there would be a risk of circumvention of that stage, which constitutes... an essential safeguard provided for by the directive. ${ }^{16}$

\footnotetext{
${ }^{9}$ Ibid. at para. 24.

${ }^{10}$ Ibid. at para. 25.

11 Ibid. at para. 25.

12 Ibid. at para. 25.

${ }^{13}$ See the Habitats Directive, above n. 2 at art 6(3).

${ }^{14}$ See People Over Wind, above n. 1 at para. 29.

15 Ibid. at para. 35.

16 Ibid. at para. 37.
} 
Referring to the case of Orleans and Others,${ }^{17}$ the Court stressed that an appropriate assessment is a safeguard as it 'may not have lacunae and must contain complete, precise and definitive findings and conclusions capable of removing all scientific doubt as to the effects of the proposed works on the protected site concerned'. ${ }^{18}$ Therefore, in a brief but unwavering conclusion, the Court answered the question of whether mitigation measures can be considered at the screening stage firmly with a negative response. This is understandable in a case which gave the impression of less stringent mitigation measures being applied because of a desire to avoid the need for an appropriate assessment, thereby categorising the cabling works as 'exempted development'.

\section{Commentary}

This judgment is clearly inconsistent with the well-established approach that has been taken to screening by the English courts over recent years. The key authority which is now in question is $R$ (on the application of Hart DC) $v$ Secretary of State for Communities and Local Government, ${ }^{19}$ otherwise known as the "Dilly Lane" case, which concerned a residential development in Hart District. In the High Court, Sullivan J was very clear in finding that mitigation measures should be taken into account in screening proposals as demonstrated in the following extracts from the judgment:

As a matter of common sense, anything which encourages the proponents of plans and projects to incorporate mitigation measures at the earliest possible stage in the evolution of their plan or project is surely to be encouraged. What would be the point, from the proponents' point of view, of going to the time, trouble and expense of devising specific mitigation measures designed to avoid or mitigate any effect on an SPA, and incorporating those proposals into the project, if the competent authority was then required to ignore them when considering whether an appropriate assessment was necessary $?^{20}$

The underlying principle to be derived from both the Waddenzee judgment and the domestic authorities... is that, as with the EIA Directive, the provisions in the Habitats Directive are intended to be an aid to effective environmental decision making, not a legal obstacle course. If, having considered the "objective information" [confirming the adequacy of the mitigation measures] it would have been "ludicrous"... to disaggregate the different elements of the package and require an appropriate assessment on the basis that the residential component of the package, considered without [mitigation measures], would be likely, in combination with other residential proposals, to have a significant effect on the SPA, only... to have to reassemble the package when carrying out the appropriate assessment. $^{21}$

Once it was accepted in Dilly Lane that mitigation measures could be taken into account at the screening stage, that approach was adopted elsewhere. In Champion v North Norfolk District Council \& Anor ${ }^{22}$ the principle of taking mitigation measures into account at the screening

\footnotetext{
${ }^{17}$ Cases C-387/15 and C-388/15 Orleans and Others [2016] ECR I-583.

${ }^{18}$ See People Over Wind, above n. 1 at para. 38.

${ }^{19}$ [2008] P \& CR 61.

${ }^{20}$ Ibid. at para. 61.

${ }^{21}$ Ibid. at para. 72 .

22 [2013] EWHC 1065 (Admin).
} 
stage was accepted, and in doing so Mr James Dingemans QC (sitting as a Deputy High Court Judge) noted:

The first proposition is that, when considering whether the test for an assessment is triggered, the relevant authority may take account of the remedial measures submitted as part of the proposal. It appeared from the Skeleton Arguments that the Claimant might dispute the first proposition, but in oral submissions, the point became effectively common ground. This appears from: Gillespie v First Secretary of State ... at paragraph 36, "when making his screening decision, the Secretary of State was not in my judgment obliged to shut his eyes to the remedial measures submitted as a part of the planning proposal" (Pill LJ); $R$ (Catt) $v$ Brighton and Hove City Council ... at paragraph 35, when Pill LJ repeated his comments and noted that there was no general principle that only uncontroversial remedial measures could be taken into account; $R$ (Hart) $v$ Secretary of State for Communities and Local Government ... at paragraph 61 the competent authority may ask the proponent of a plan or project for more information about the plan or project, including any proposed mitigation, not merely for the purposes of carrying out an appropriate assessment, but also in order to determine whether an appropriate assessment is required in the first place; and $R$ (Loader) $v$ Secretary of State ... paragraph 64 "it is now common ground between the parties that it is open to the decision maker, in performing the screening exercise, to take into account mitigating measures." 23

This analysis built upon Sullivan J's approach in Dilly Lane, drawing upon EIA case law. ${ }^{24}$ Doing this made the approach under the Habitats Regulations consistent with EIA. This seemed both helpful and pragmatic, particularly where both regimes are dealing with the same ecological impacts. Consideration of mitigation measures was also affirmed in Feeney $v$ Secretary of State for Transport, ${ }^{25}$ where the High Court determined that the conditions that had been imposed on planning permission for development had been appropriate, resulting in a finding that no appropriate assessment was necessary.

In Smyth $v$ The Secretary of State for Communities and Local Government \& Ors ${ }^{26}$ the Court of Appeal agreed with Sullivan J's approach in Dilly Lane. Sales LJ said that Sullivan J's approach was compelling, clearly correct and 'to the act eclair standard'. ${ }^{27}$ Sales LJ said it was 'clear from the relevant case-law that preventive safeguarding measures are relevant matters to be taken into account under an "appropriate assessment" under the second limb' and also that there is 'compelling logic to say that they are relevant and may properly be taken into account in an appropriate case under the first limb of Article 6(3) as well' ${ }^{28}$ AG Kokott's Opinion in Waddenzee was drawn on to conclude that 'preventive safeguarding measures as relevant to both limbs of Article 6(3) '. ${ }^{29}$ According to Sales LJ it would be 'disproportionate and unduly burdensome... to undergo the delay, effort and expense of going through an entirely

\footnotetext{
${ }^{23}$ Ibid. at para. 40.

${ }^{24} \mathrm{R}$ (on the application of Catt) v Brighton and Hove CC [2007] EWCA Civ 298; Gillespie v First Secretary of State [2003] EWCA Civ 400; R (Loader) v Secretary of State [2011] EWHC 2010 (Admin).

${ }^{25}$ [2013] EWHC 1238 (Admin).

${ }^{26}$ [2015] EWCA Civ 174.

${ }^{27} \mathrm{Ibid}$ at para. 74.

${ }^{28}$ Ibid. at para. 75 .

${ }^{29}$ Ibid. at para 75 .
} 
unnecessary additional stage, 30 and that these are 'powerful indicators that the proper interpretation of Article 6(3) is as set out by Sullivan J'. ${ }^{31}$

The issue was raised again in the Supreme Court decision of $R$ (on the application of Champion) $v$ North Norfolk $D C,{ }^{32}$ with Lord Carnwath expressing that:

In the present case, in the light of the new information provided and the mitigation measures developed during the planning process, the competent authority, in common with their expert consultees, were satisfied that any material risk of significant effects on the SAC had been eliminated. Although this was expressed by the officers as a finding that no appropriate assessment under article 6(3) was required, there is no reason to think that the conclusion would have been any different if they had decided from the outset that appropriate assessment was required, and the investigation had been carried out in that context... The mere failure to exercise the article 6(3) "trigger" at an earlier stage does not in itself undermine the legality of the final decision. ${ }^{33}$

This brief exploration of recent judgments from English courts demonstrates that a clear pattern had formed asserting that mitigation measures can be considered at the screening stage under the Habitats Regulations. Following the CJEU decision of People Over Wind, this assertion has been blown out of the water. Now People Over Wind is the definitive authority on whether mitigation measures can be taken into account at the screening stage. This new position means that competent authorities will be required to undertake a full appropriate assessment of the mitigation measures being relied upon.

Whilst this interpretation differs from English case law, it is not wholly unexpected. An analysis of the European Commission's guidance regarding managing Natura 2000 sites, combined with the accompanying Methodological Guidance shows that no reference is made to mitigation at the screening stage. ${ }^{34}$ This inconsistency, and the need for a reference to the CJEU for a definitive ruling, was one of the points argued in Smyth, prompting Sales LJ's comments above. In Champion, whilst Dilly Lane was relied upon, Lord Carnwath noted:

There is nothing in the language of the Habitats Directive to support a separate stage of "screening" in any formal sense. Nor is it reflected in the reasoning of the CJEU itself... The same approach is also found in the European Commission's guidance Managing Natura 2000 Sites: The Provisions of article 6 of the 'Habitats' Directive 92/43/EEC... ${ }^{35}$

\footnotetext{
${ }^{30}$ Ibid. at para. 76 .

${ }^{31}$ Ibid. at para. 77.

32 [2015] UKSC 52.

${ }^{33}$ Ibid. at para. 42.

34 'Managing Natura 2000 Sites: The provisions of Article 6 of the 'Habitats' Directive 92/43/EEC' (European Commission, 2000). Available at:

http://ec.europa.eu/environment/nature/natura2000/management/docs/art6/provision_of_art6_en.pdf (last accessed 6 June 2018); 'Assessment of plans and projects significantly affecting Natura 2000 sites: Methodological guidance on the provisions of Article 6(3) and (4) of the Habitats Directive 92/43/EEC' (European Commission, November 2001). Available at: http://ec.europa.eu/environment/nature/natura2000/management/docs/art6/natura_2000_assess_en.pdf (last accessed 6 June 2018).

${ }^{35}$ See Champion, above n. 32 at para. 37.
} 
The strong purposive interpretation of the requirements of the Habitats Directive from the CJEU also comes as no surprise considering parallels that can be drawn to the case law concerning SPA and SAC site designation ${ }^{36}$ - all of which demonstrate the insistence of the European Courts to preserve the spirit and purpose of the Habitats Directive by ensuring that protected sites are properly designated by Member States, and where they have not been, that they receive the same protection that they should have received had they have been correctly designated.

\section{Consequences}

By allowing for the consideration of mitigation measures at screening, the English Courts since Dilly Lane have interpreted screening under the Habitats Regulations as identical to screening under EIA. People Over Wind reasserts the distinctiveness of the Habitats Directive which, in the spirit of the stricter protection it is designed to create, treats the scrutiny of mitigation measures differently. It is crucial now not to confuse the approach to screening under EIA with that under the Habitats Directive. Lord Carnwath warned against this risk in Champion:

This informal threshold decision is not to be confused with a formal "screening opinion" in the EIA sense. The operative words are those of the Habitats Directive itself. $^{37}$

This is understandable from a theoretical point of view, however in practice it will be difficult to explain why there is a difference in approach between EIA and Habitats Directive when they are considering the same environmental impacts. That loss of a pragmatic read across is even harder to explain given Sullivan J's remarks that it would be 'ludicrous' to ignore mitigation measures at screening and Sales LJ's comment that this would be 'disproportionate and unduly burdensome' as outlined above.

Now that mitigation measures must be considered through appropriate assessment, this will inevitably mean more assessments will be needed. However, in practice this should mean a reallocation of work currently carried out at screening so that this is now called appropriate assessment. Where a rigorous approach to screening has been taken, there is no reason to think that the conclusion would have been different if it had been decided from the outset that an appropriate assessment was necessary. ${ }^{38}$ The statutory nature conservation body will, however, need to be formally consulted on each appropriate assessment and time will need to be factored in for this. If developers are concerned about delays then they should ensure that they enter into early, pre-application conversations with Natural England to ensure that there is close working over mitigation measures in advance of applications being submitted. This will assist in terms of more streamlined consultations on appropriate assessments. English planning policy

\footnotetext{
${ }^{36}$ For example, in Case C-1/100 Commission of the European Communities v French Republic [2001] ECR I-687 the court insisted that sites that should have been designated as an SPA, but have not been, were still entitled to the higher level of protection that was afforded by the Directive. In Case C-355/90 Commission of the European Communities v Kingdom of Spain [1993] ECR I-331 the Spanish Government was found to be in breach of its obligations under Article 4 by failing to designate an important wetland area as an SPA. This same purposive stance was followed in the cases of C-44/95 R v Secretary of State for the Environment ex parte Royal Society for the Protection of Birds [1996] ECR I-297 and C-3/96 Commission v Netherlands [1999] Env LR 147.

${ }^{37}$ See Champion, above n. 32 at para. 41.

${ }^{38}$ See Lord Carnwath's comments in Champion, above n. 32 at para 41.
} 
will also need to catch up with the new judgment. The golden thread that runs through the National Planning Policy Framework is sustainable development. This can be interpreted to mean that matters requiring appropriate assessment are not sustainable because of the assumption that if they had no impact on a designated site they would have been screened out. This will now need to be interpreted in light of People Over Wind.

It would be a tragedy if People Over Wind meant that less work was put into mitigation measures at the pre-application stage because of the inevitability of going to appropriate assessment, resulting in plans and projects which are simply tweaked in order to get them below the threshold of adverse effect on integrity. This might mean that measures intended to entirely eliminate impacts, and thereby be screened out at the likely significant effect stage, are dropped in favour of mitigation options that just avoid adverse effects on integrity. In our view there is no justification for this. Article 6 should be read in a stepwise fashion with, in the first instance, steps taken to conserve and enhance sites under Article 6(1) as well as steps to avoid disturbance and damage under Article 6(2) before consideration is given to mitigation under Article 6(3). This is the proper context in which plans and projects should be considered.

In addition to the potential increase in resources needed within the sector, confusion may occur amongst developers with regards to which parts of a plan or project's mitigation measures intend to avoid or reduce harm. This could result in an increase in queries to competent authorities causing delays and further costs as well as delays in the preparation of planning applications. To avoid this the safest option is likely to be when in doubt, carry out an appropriate assessment and avoid a People Over Wind challenge.

The need for an appropriate assessment may also trigger other procedural requirements under environmental law. These further procedural requirements may lead to further requirements to formally consult and that will need to be factored into decision making and planning.

\section{Conclusion}

There may be further twists in this tale. Perhaps the Irish High Court or another Member State will ask for further clarification from the CJEU. Perhaps English courts will agree that a distinction can be made between mitigation measures that are built into a plan or project and mitigation measures which are additional to the plan or project designed to cancel out or minimise the adverse effects. Perhaps a narrow interpretation of People Over Wind will be adopted along the lines that appropriate assessment of mitigation measures is not necessary if those mitigation measures have been appropriately assessed and accepted as successful in previous (identical) cases. It might also be decided that People Over Wind turns on its own facts and that no generally applicable rules flow from it. Some or all of these arguments might be made arising out of the nuanced circumstances of particular cases.

We will have to wait and see. In the meantime, this minimalist and pithy CJEU judgment is all that we have to go on, along with the fact that it is clear that in the context of Article 6(3) of the Habitats Directive it is not appropriate, at the screening stage, to take account of the measures intended to avoid or reduce the harmful effects of a plan or project. 